\title{
Tube morphology, ultrastructures and mineralogy in recent Spirorbinae (Annelida: Polychaeta: Serpulidae). I. General introduction. Tribe Paralaeospirini
}

\author{
A.P. Ippolitov ${ }^{1}$, A.V. Rzhavsky² \\ ${ }^{I}$ Geological Institute of Russian Academy of Sciences (GIN RAS), 7 Pyzhevskiy per., Moscow, \\ Russia, 119017, e-mail: ippolitov.ap@gmail.com \\ ${ }^{2}$ A.N. Severtsov Institute of Ecology and Evolution of Russian Academy of Sciences (IPEE RAS), 33 \\ Leninskiy prosp., Moscow, Russia, 119071,e-mail:rzhavskij@mail.ru
}

ABSTRACT: This report is the first part of a series of papers that provide an overview of tube morphology, mineralogy, and ultrastructures within the subfamily Spirorbinae, including the discussion of taxonomic and phylogenetic significance of the tube features. This paper reviews published data on the subject and provides descriptions of ultrastructure and mineralogy for the tribe Paralaeospirini Knight-Jones, 1978. The species of the tribe have uniformly simple calcitic unilayered tubes of the same irregularly oriented prismatic (IOP) ultrastructural type, which is regarded as plesiomorphic among serpulids.

How to cite this article: Ippolitov A.P., Rzhavsky A.V. 2014. Tube morphology, ultrastructures and mineralogy in recent Spirorbinae (Annelida: Polychaeta: Serpulidae). I. General introduction. Tribe Paralaeospirini // Invert. Zool. Vol. 11. No. 2.

KEY WORDS: Tube ultrastructures, tube morphology, tube mineralogy, scanning electron microscopy, X-ray diffraction analysis, Spirorbinae, Paralaeospirini.

\section{Морфология, ультраструктуры и минералогия трубок современных Spirorbinae (Annelida: Polychaeta: Serpulidae). І. Общее введение. Материал и методы. Триба Paralaeospirini}

\begin{abstract}
А.П. Ипполитов ${ }^{1}$, А.В. Ржавский ${ }^{2}$
${ }^{1}$ Геологический институт РАН, Пыжевский пер. 7, Москва, Россия, 119017, е-таil: ippolitov.ap@gmail.com

${ }^{2}$ Институт проблем экологии и эволючии им. А.Н. Северцова РАН, Ленинский пр. 33, Москва, Pоссия,119071,e-mail: rzhavskij@mail.ru

РЕЗЮМЕ: В настоящей серии статей приводится обзор морфологического, ультраструктурного и минералогического разнообразия трубок подсемейства Spirorbinae, а также обсуждается возможное таксономическое и филогенетическое значения признаков трубок. В первой части серии мы приводим обзор опубликованных данных, а также даем описания морфологии трубок, их ультраструктур и минералогии для трибы Paralaeospirini Knight-Jones, 1978. Установлено, что виды, представляющие трибу, имеют однослойные кальцитовые трубки из хаотически ориентированных призматических кристаллов. Данный тип строения трубок интерпретируется как архаичный для серпулид.
\end{abstract}


Как цитировать эту статью: Ippolitov A.P., Rzhavsky A.V. 2014. Tube morphology, ultrastructures and mineralogy in recent Spirorbinae (Annelida: Polychaeta: Serpulidae). I. General introduction. Tribe Paralaeospirini // Invert. Zool. Vol. 11. No. 2.

КЛЮЧЕВЫЕ СЛОВА: Ультраструктура трубок, морфология трубок, минералогия трубок, сканирующая электронная микроскопия, рентгенодифракционный анализ, Spirorbinae, Paralaeospirini.

\section{Introduction}

Subfamily Spirorbinae of the family Serpulidae Rafinesque, 1815 is a widely distributed group of small marine polychaetes that inhabit calcareous tubes tightly coiled into spirals and attached to a variety of substrata. Recent spirorbins have world-wide distribution ranging from littoral to abyssal depths, but are most commonly found in the sublittoral zone.

Family Serpulidae was traditionally subdivided into subfamilies Spirorbinae Chamberlin, 1919, Serpulinae Rafinesque, 1815, and Filograninae Rioja (1923) (e.g., Rioja, 1923; Fauvel, 1927). Pillai (1970) elevated Spirorbinae to the family status, which was accepted both in Recent and fossil taxonomy (e.g., Knight-Jones P., Fordy M., 1979; Lommerzheim, 1981; Jäger, 1993, 2005; Rzhavsky, 1994). Later numerous authors (e.g., ten Hove, 1984; Smith, 1991, Kupriyanova, 2003; Kupriyanova et al., 2006; Lehrke et al., 2007), based on the results of phylogenetic analyses of morphological and molecular data, concluded that spirorbins constitute a monophyletic group nested inside the Serpulidae. Therefore, the rank of the spirorbids was lowered to the subfamily and all former subfamilies established within Spirorbidae (see Knight-Jones P., Fordy, 1979) became tribes (Rzhavsky et al., 2013). The current state of classification of Spirorbinae that includes 6 tribes, 24 genera, and 131 (135?) species is summarized in Table 1.

Spirorbin fossil record. Spirorbins calcareous tubes have a good potential to fossilize, providing a basis for substantial fossil record for these polychaetes. Contrary to the long-held view (e.g., Goldfuss, 1831; Zittel, 1880; Howell, 1962; Pillai, 1970; Lommerzheim, 1979,
1981; Jäger, 1983, 1993) that spirorbins are an ancient group dating back to the Ordovician period ( 445-485 $\left.\mathrm{Ma}^{1}\right)$, true spirorbins seem to appear from the Latest Jurassic or Earliest Cretaceous ( 145 Ma: see Taylor, Vinn, 2006). Non-spirorbin nature of more ancient Paleozoic to Early Mesozoic tubes, which look undistinguishable from spirorbins by external morphology, was recognized by morphology of their internal septae (Burchette, Riding, 1977), study of tube microstructures (Burchette, Riding, 1977; Weedon, 1990, 1991) and comparison with those of Recent forms (Weedon, 1994; Taylor, Vinn, 2006). These ancient fossils are now placed not only outside Spirorbinae, but also outside the phylum Annelida (see Vinn, Taylor, 2007).

During the Cretaceous period (145-66 Ma), coiled serpulids attributed to spirorbins were represented mostly by the large-sized and peculiar genus Neomicrorbis Rovereto, 1903. The most ancient finds of this genus are described from the Late Barremian ( 128 Ma; Jäger, 2011), but finds of somewhat similar tubes are more ancient (see Jäger, 1983, 1993, 2011). Neomicrorbis tubes, unlike most spirorbins, are coiled in any direction and often have characteristic sculpture of numerous rows of tiny tubercules. Information on the body morphology available from the only known Recent species Neomicrorbis azoricus Zibrowius, 1972 (Zibrowius, 1972; Hove, Kupriyanova, 2006) does not allow to make a certain conclusion about its phylogenetic position inside Serpulidae.

Unquestionable spirorbin species that appeared in the middle of the Early Cretaceous

\footnotetext{
${ }^{1}$ Absolute ages are provided according to official site of the International Commission of Stratigraphy (www.stratigraphy.org/GSSP/index.html), accessed 0103-2013.
} 
Tube morphology, ultrastructures and mineralogy in recent Spirorbinae. I.

Table 1. Compiled classification of Recent spirorbins, including tribes, genera and number of valid species. Some species of uncertain generic affinity are not considered in the table.

Таблица 1. Классификация современных спирорбин (трибы, рода и число валидных видов). Некоторые виды неясной родовой принадлежности не учтены.

\begin{tabular}{|c|c|c|}
\hline Tribe & Genus & $\begin{array}{c}\text { Number of } \\
\text { species }\end{array}$ \\
\hline Paralaeospirini Knight-Jones, 1978 & Paralaeospira Caullery et Mesnil, 1897 & 10 \\
\hline \multirow{2}{*}{ Incertae sedis (Paralaeospirini?) } & Anomalorbis Vine, 1972 & 1 \\
\hline & Crozetospira Rzhavsky, 1997 & 1 \\
\hline Spirorbini Chamberlin, 1919 & Spirorbis Daudin, 1800 & 15 \\
\hline \multirow{2}{*}{ Circeini Knight-Jones, 1978} & Circeis Saint-Joseph, 1894 & 6 \\
\hline & Paradexiospira Caullery et Mesnil, 1897 & $3(4 ?)$ \\
\hline \multirow{6}{*}{ Romanchellini Knight-Jones, 1978} & Eulaeospira Pillai, 1970 & 2 \\
\hline & Helicosiphon Gravier, 1907 & 1 \\
\hline & Knightjonesia Pillai, 2009 & 1 \\
\hline & Metalaeospira Pillai, 1970 & 4 \\
\hline & Protolaeospira Pixell, 1912 & 12 \\
\hline & Romanchella Caullery et Mesnil, 1897 & 8 \\
\hline \multirow{4}{*}{ Januini Knight-Jones, 1978} & Janua Saint-Joseph, 1894 & 1 \\
\hline & Leodora Saint-Joseph, 1894 & 1 \\
\hline & Neodexiospira Pillai, 1970 & 10(11?) \\
\hline & Pillaiospira Knight-Jones, 1973 & 3 \\
\hline \multirow{7}{*}{ Pileolariini Knight-Jones, 1978} & Amplicaria Knight-Jones, 1984 & 1 \\
\hline & Bushiella Knight-Jones, 1973 & $13(14 ?)$ \\
\hline & Nidificaria Knight-Jones, 1984 & 8 \\
\hline & Pileolaria Claparède, 1868 & $21(22 ?)$ \\
\hline & Protoleodora Pillai, 1970 & 4 \\
\hline & Simplaria Knight-Jones, 1984 & 3 \\
\hline & Vinearia Knight-Jones, 1984 & 3 \\
\hline Incertae sedis & Neomicrorbis Rovereto, 1903 & 1 \\
\hline
\end{tabular}

(Late Barremian; 126 Ma; Jäger, 2011) are represented by tubes, morphologically comparable with those of extant species of genera Pileolaria and Neodexiospira. From the latest Cretaceous (Late Maastrichtian; 66 Ma) spirorbins became a very common element of encrusting communities (e.g., Jäger, 1983, 1993). Younger Paleogene (Paleocene, 62-59 Ma; Lommerzheim, 1981) and especially Neogene (like Badenian, 16-13 Ma; Radwańska, 1994, etc.) sediments already contain highly diversified spirorbin communities similar to Recent ones.

Classification of Recent spirorbins is currently built around the methods of embryos incubation, as well as body and chaetal characters, while tubes are mostly neglected. This approach walls off paleontologists who work predominantly with tubes and rarely calcified opercula. In non-spirorbin serpulids tube mor- phology is less uniform and better studied to allow classification of fossil species within Recent genera (see Jäger, 1993, 2005), while for spirorbins determination of generic affinity based on empty tubes remains problematic. As a result, despite existing fossil record, zoologists still have no reliable paleontological data for understanding evolutionary history of the group, while paleontologists are restricted in their geological, paleoecological, and biogeographical interpretations because no direct comparison of fossils with Recent taxa is possible. If determinations of fossil spirorbin tubes from Late Barremian $(\sim 126 \mathrm{Ma})$ are correct, this means that two of the Recent tribes characterized by complex incubation methods (Pileolariini and Januini) have already established in the middle Early Cretaceous, suggesting that the main diversification of spirorbins should take place before. 
Tube ultrastructures and mineralogy and their potential in decrypting paleontological record. Serpulid tube ultrastructural diversity has a good potential for decrypting their paleontological record. It became obvious as a result of the early studies (Bohnné Havas, 1981; Bubel et al., 1983; Bandel, 1986; ten Hove, Zibrowius, 1986; Zibrowius, ten Hove, 1987) that calcium carbonate crystals of the tube wall may have a variety of shapes and sizes, and may be arranged in different ways. Studies over the last two decades revealed outstanding ultrastructural diversity in serpulid tubes (e.g., Nishi, 1993; Sanfilippo, 1998a,b, 2001; Vinn, 2005, 2007, 2008; Vinn et al., 2008a), which is currently classified into 13 ultrastructural types (Vinn et al., 2008a,b).

The idea to evaluate generic affiliation of fossil serpulid species using tube ultrastructures was first proposed by Sanfilippo (1998b). In Recent forms tube transparency can be a result of certain ultrastructural characters (ten Hove, Zibrowius, 1986; Ippolitov, Rzhavsky, 2008; Vinn et al., 2008a; Vinn, Kupriyanova, 2011); in one case such tube wall ultrastructure was included into the diagnosis of species [Placostegus tridentatus (Fabricius, 1780), see Sanfilippo, 2003]. Vinn et al. (2008a), who have analyzed the largest set of tubes scattered among serpulid genera, concluded that ultrastructure is more likely to be a specific character rather than a generic one. This assumption devaluates ultrastructures as a tool for determining generic affinity of fossils. However, some outline of evolutionary interrelations of different ultrastructural types can be provided (e.g., Vinn et al., 2008a; Vinn, Kupriyanova, 2011; Vinn, 2013), and together with fossil record analysis, this approach can be used for decrypting the evolutionary interrelations of major clades (sen$s u$ Kupriyanova et al., 2009) within Serpulidae. Tube ultrastructures in some serpulids have been also shown to have adaptive significance (Vinn et al., 2008a,b; Tanur et al., 2009; Vinn, Kupriyanova, 2011), but these investigations do not provide any connections to taxonomy for the moment. The approach of a systematic analysis of ultrastructural diversity within closely related groups of species adopted in this inves- tigation has not been previously applied to any serpulid genera, and can potentially shed light on the problem of empty tube generic affiliation.

Mineralogical investigations, in particular, estimating the calcite-aragonite ratio of serpulid tubes, received little attention. Lowenstam (1954) has shown that calcium carbonate of serpulid tubes may be represented by calcite, aragonite, or their mixture. The first comprehensive overview of serpulid tube mineralogy was presented by Bornhold and Milliman (1973) who analyzed over 100 specimens belonging to 30 species from 15 genera. Their results showed no correlations of mineralogical composition with temperature, and also no correlations were found with taxonomic groups (genera). Moreover, calcite-aragonite ratio significantly varied not only among, but also within species, and even within a single tube (Bornhold, Milliman, 1973). Vinn et al. (2008a) has demonstrated some correlations of mineralogy with ultrastructural types, but no clear correlations with taxonomy (genera) were found. The most recent comprehensive analysis (Smith et al., 2013) of both published and new data has shown that phylogenetic factor is the most important for understanding tube mineralogy. Like in case of ultrastructures, mineralogical composition of tubes shows more or less clear correlations with large clades of Serpulidae sensu Kupriyanova et al. (2009).

Spirorbin tube ultrastructures and mineralogy. All the ultrastructural and mineralogical investigations so far covered mainly non-spirorbin Serpulidae. Spirorbin ultrastructures were not included in most extensive overview of serpulid tubes by Vinn et al. (2008a). The only paper focused on Spirorbinae was published by Ippolitov and Rzhavsky (2008). A list of spirorbin species with published and figured tube ultrastructures counts eight Recent species, which are not always correctly identified:

1. Neodexiospira sp., probably Neodexiospira foraminosa (Bush in Moore et Bush, 1904); originally determined as Janua steueri (Sterzinger, 1909) (see Nishi, 1993, Fig. 1F). 
2. Spirorbis cf. rupestris Gee et KnightJones, 1962 (see Weedon, 1994, Fig. 3; in fact it is probably not a true Spirorbis).

3. Spirorbis spirorbis (Linnaeus, 1758); also fossil material (Early Pleistocene; $1.8-1 \mathrm{Ma}$ ) from Mediterranean region was studied (see Sanfilippo, 1998a, Pl. 2).

4. Spirorbis sp. (see Taylor, Vinn, 2006, Fig. 1D; can be identified only as "Spirorbinae sp.").

5. Spirorbis rothlisbergi Knight-Jones, 1978 (see Ippolitov, Rzhavsky, 2008, Fig. 1a).

6. Protolaeospira (Dextralia) stalagmia Knight-Jones et Walker, 1972 (see Ippolitov, Rzhavsky, 2008, Fig. 1c).

7. Protolaeospira augeneri Vine, 1977 (see Ippolitov, Rzhavsky, 2008, Fig. 1d).

8. Protoleodora uschakovi Knight-Jones, 1984 (see Ippolitov, Rzhavsky, 2008, Fig. 1b).

Nishi (1993, tab. 1) provided crystal measurements for one more species, "Pileoralia [sic!] girdis" (probably = ?Pileolaria sp.; name unknown in literature), but has not accompanied them with any description or figure. Five more specimens of Spirorbis spp., without further specification, ranging from Pliocene to Recent, have been only referred to have "fine-grained" tubes (Taylor, Vinn, 2006). Also, two species of Recent "Spirorbis spp." (Weedon, 1994) and a fossil species from the Early Santonian ( $~ 86$ Ma) of UK mentioned as "Spirorbis plana (Woodward)" [probably should be referred to Neomicrorbis crenatostriatus subrugosus (Münster in Goldfuss, 1831)] were stated to have studied ultrastructures (Taylor, Vinn, 2006); however, no descriptions or figures were provided.

Most authors found spirorbins to have simple unilayered tubes consisting of ricegrain-like crystals, oriented chaotically. But it also was shown (Ippolitov, Rzhavsky, 2008) that like in serpulids inner and outer tube surfaces are often strengthened by different types of ultrastructures, providing consolidation of the tube wall - "dense layers" sensu Vinn and Kupriyanova (2011). The main conclusion of Ippolitov, Rzhavsky (2008) was that spirorbin tube ultrastructures are not uniform. After the diversity of Recent non-spirorbin serpulids became known
(Vinn et al., 2008a,b), it should be stated that spirorbin ultrastructural diversity is comparable with that of other serpulids. Both in non-spirorbin serpulids and spirorbins, studies of tube ultrastructures can potentially become useful for estimating generic affiliations.

Mineralogical data on spirorbin tubes are also scarce. Bornhold and Milliman (1973) mention two specimens of Spirorbis borealis Daudin, 1800 (junior objective synonym of Spirorbis spirorbis (Linnaeus, 1758)). One of them was found to be pure calcitic, while another had $10.5 \%$ aragonite content. Neither data on accuracy of the analysis, nor any morphological characteristics confirming the determinations are available.

Objectives of study. The aims of the present investigation are 1) to provide comprehensive descriptions of mineralogy and ultrastructures of spirorbin tubes covering as many Recent species as possible and 2) to examine potential correlations of ultrastructural and mineralogical characters with taxonomic groups, tube morphology, as well as with ecological and biogeographical patterns.

The results of our study will form a series of papers, each of them dealing with a tribe of Spirorbinae. Tribes will be presented in the order of growing complexity of their brooding methods (Paralaeospirini $\rightarrow$ Spirorbini $\rightarrow$ Circeini $\rightarrow$ Romanchellini $\rightarrow$ Januini $\rightarrow$ Pileolariini), while genera within tribes and species within genera will be arranged in alphabetical order. Conclusions on each tribe, as well as corresponding discussions, will be provided in the relevant parts, while the extended general discussion will be published in the last paper of the series.

\section{Tube morphology and terminology}

Spirorbins live in small tubes coiled into spirals 1.5-4 (up to 8) $\mathrm{mm}$ in diameter, attached to substrate and containing up to 5 coils. Normally the spirals are flat, but distal parts may be uncoiled (evolute) and raising above the substrate (Fig. 1C), with overlapping coils, or 

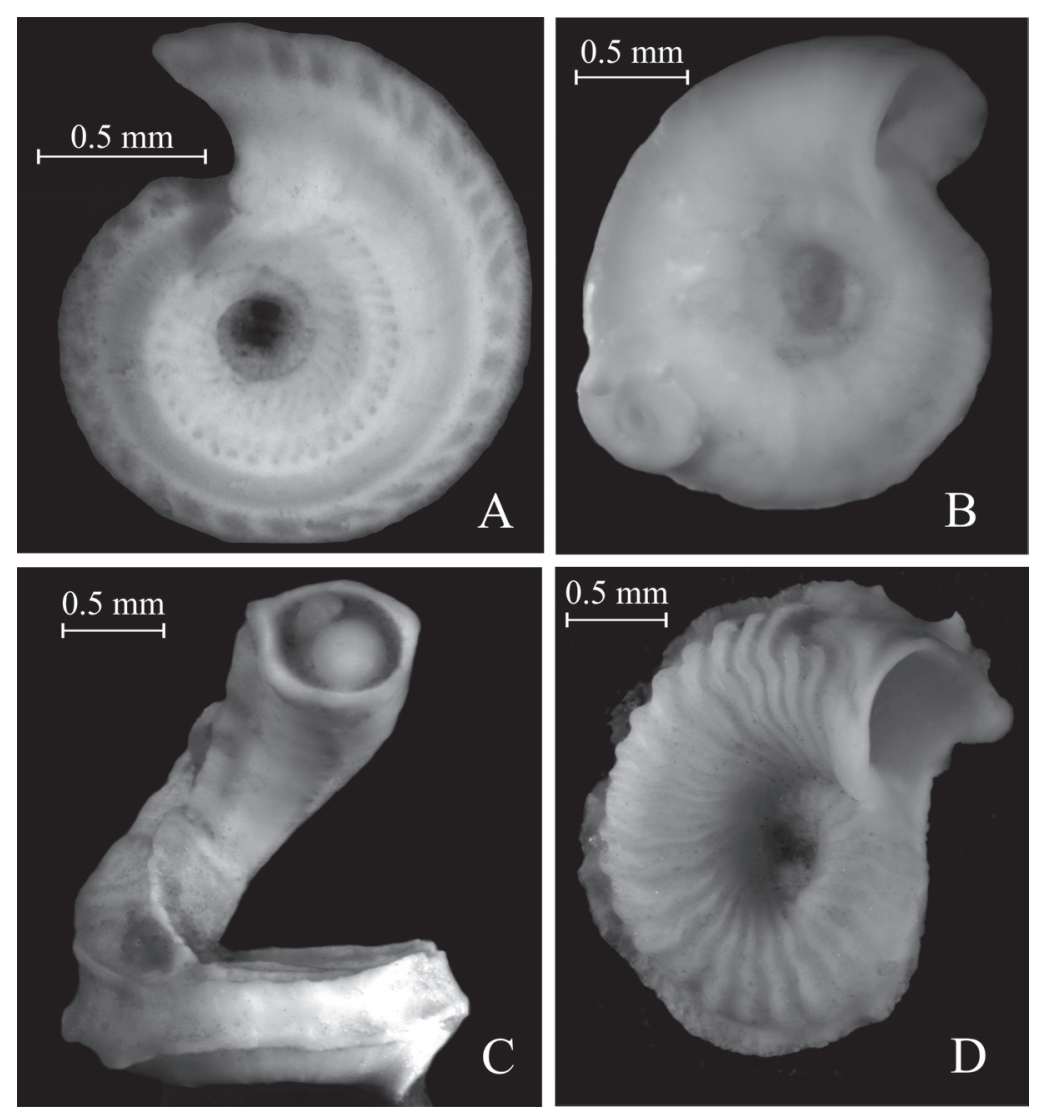

Fig. 1. External morphology of Spirorbinae tubes. A - Neodexiospira alveolata (Zachs, 1933): dextral (anticlockwise) tube with longitudinal keels and alveoli; B - Bushiella (Jugaria) similis (Bush, 1905): sinistral (clockwise) unsculptured tube; C - Bushiella (Jugaria) kofiadii Rzhavsky, 1988: sinistral (clockwise) tube with three longitudinal keels and tube mouth facing upward from substrate; D Protolaeospira eximia (Bush, 1905): sinistral (clockwise) tube with transverse ridges.

Рис. 1. Внешняя морфология трубок спирорбин. А - Neodexiospira alveolata (Zachs, 1933): правозакрученная (против часовой стрелки) трубка с продольными килями и альвеолами; В - Bushiella (Jugaria) similis (Bush, 1905): левозакрученная (по часовой стрелке) нескульптурированная трубка; C - Bushiella (Jugaria) kofiadii Rzhavsky, 1988: левозакрученная (по часовой стрелке) трубка с тремя продольными килями и приподнятым над субстратом устьем; D - Protolaeospira eximia (Bush, 1905): левозакрученная (по часовой стрелке) трубка с поперечными гребнями.

straight and attached to the substrate. Among completely attached forms, tubes may have all the coils well visible or the later coils may partly or completely cover the previous ones, resulting in hiding the entire spiral by the last coil (see Rzhavsky, 1994, Fig. 1G, J). Coiling direction can be clockwise (sinistral; Fig. 1B-D) or anticlockwise (dextral; Fig. 1A). To determine the direction of the coiling, tubes should be observed from the upper side, opposite the sub- strate. Most species are known to have only one coiling direction, but tubes of several Spirorbis species may coil in either direction, and all species of Neomicrorbis normally coil in either direction. Rarely, some Circeini and Januini (normally dextral) may have specimens with clockwise coiling, but dextral specimens have never been recorded among typically sinistral species.

Tubes may be unsculptured (Fig. 1B) or have external ornamentation (sculpture) on the 
tube surface. Typically it consists of longitudinal (Fig. 1A, C) or transverse (Fig. 1B) elements. A single major prominent longitudinal keel or several parallel keels, often termed longitudinal ridges (usually $2-5$, but up to 10 and even more in Neomicrorbis), may be present. The keels may either be sharp or obtuse, high or low, or have the appearance of longitudinal rows of larger denticles and smaller tubercules. In most cases all keels are equally developed, but often certain keels (usually the median one) can be better pronounced. Transverse tube ornamentation in spirorbins may be presented by regularly spaced transverse collar-like ridges, sometimes interpreted as growth stops. Also, in some spirorbins tube surface may be completely or partially pitted by alveoli (Fig. 1A) that sometimes completely perforate keels. Attached tube parts often produce flattened peripheral flanges that also may contain regularly spaced alveolar structures.

Tubes are usually chalky white (opaque), rarely they may be completely transparent (vitreous) or partially transparent (semitransparent) or somewhat transparent, the last state is probably caused by the low thickness of the wall. In spirorbins with vitreous tubes the coloured inner lining of the tube or the body of live specimens may be seen through tube walls. The tube surface may be rough, more or less smooth, or smooth with shining (porcellanous) outer layer.

\section{Terminology of ultrastructures}

We follow the classification of ultrastructures and their terminology developed for Recent serpulids by Vinn et al. (2008a) and based on classification of carbonate ultrastructures by Carter et al. (1990). They distinguish 12 types of ultrastructures arranged in 1 to 4 wall layers, and one additional type was described separately (Vinn et al., 2008b). These types are usually referred to by abbreviations of their full names.

The term "parabolic structure" widely used in older paleontological literature (= "chevron" structure of Weedon (1994)) was transformed in Vinn's papers into "parabolic growth lines" or "parabolic lamellae". Because the configura- tion of growth lines does not correlate with appearance of crystals, and thus, cannot be interpreted as a character related to ultrastructure, therefore, we follow Vinn's suggestion.

The term "layer" in application to serpulid tubes needs some clarification. It is not always possible to distinguish layers within the wall based on different amount of amorphous cement, as was proposed by Vinn et al. (2008a: 643). In such case, multiple contradictive interpretations of layers number become possible, depending, for example, on the method of study. Also, crystal appearance can gradually change within a wall (Vinn et al., 2008a; and below), forming slight transitions from one "layer" to another. In the present series we use term "layer" only for well-delimited longitudinally structural elements, distinguishable by the certain shape and/or size of crystals, while in all other cases more neutral terms "outer", "middle" and "inner part/zone" of the wall/layer are used. This terminology is consistent with that of Weedon (1994).

\section{Material and methods}

The study is based on a collection of spirorbin tubes made by A.V. Rzhavsky and deposited in A.N. Severtsov Institute of Ecology and Evolution, Russian Academy of Sciences, Moscow (IPEE RAS). Two specimens of Neomicrorbis azoricus were obtained from the collections of P.P. Shirshov Institute of Oceanology of Russian Academy of Sciences, Moscow (SIORAS). Although the tubes studied with scanning electron microscopy (SEM) and analyzed for mineralogy have been destroyed, conspecific tubes from the same samples are available in the collection. Over 750 SEM microphotographs and $70 \mathrm{X}$-ray diffraction diagrams were obtained and analyzed, and a number of photographs of tubes were taken to illustrate external tube morphology.

For the SEM dried tubes were cracked mechanically and covered with a thin layer of gold or platinum. We used longitudinal sections running along the lateral sides of the tube. This direction of sectioning allows observing para- 
bolic growth lines ("parabolic lamellae", "chevrons" sensu Weedon, 1994). For most species we studied both external (outside the whorl) and internal (near the centre of whorl) walls of the tube, however, descriptions are primarily based on longitudinal sections of the external wall, which are the most informative. In some species tube cross sections were also studied. No special etching techniques were used to prepare sections. Although sections are often embedded into epoxide resin with subsequent polishing and etching, both literature (Bohnné Havas, 1981; Weedon, 1994) and our comparative etching trials using four agents (hydrogen peroxide, Javel water, formylic acid and acetic acid) showed that thin details of ultrastructure, such as crystal appearance, are better seen in simple fractures than in polished etched material. Sections were observed using a CamScan electron microscope in the Office of Instrumental Analytics of Paleontological Institute of Russian Academy of Sciences, Moscow (PIN RAS) and a Vega-Tescan microscope in the Electron Microscopy Laboratory of IPEE RAS (Moscow). In total, tubes of over 70 species from all 6 Spirorbinae tribes were studied with SEM, thus, covering $53 \%$ of total Recent spirorbin richness. When possible, we examined several specimens of each species to assess potential intraspecific variability of ultrastructures.

For X-RAY diffraction analysis spirorbin tubes pounded into powder were analyzed with an X-ray diffractometer DRON-3M in the laboratory of the Geological Faculty of Moscow State University (GF MSU). Signal was analyzed in the interval $30-36^{\circ} 2 \theta$ with step $0.1^{\circ}$, containing major peaks of both calcite $\left(34.35^{\circ}\right.$ $2 \theta$; corresponding spacing between diffracting planes $\mathrm{d}=3.04 \mathrm{~A})$ and aragonite $\left(31.00^{\circ}\right.$ and $31.652 \theta$; corresponding spacing between diffracting planes $\mathrm{d}=3.40 \mathrm{~A}$ and $\mathrm{d}=3.29 \mathrm{~A}$, respectively). Calcite/aragonite ratio was calculated using $\mathrm{Ca} / \mathrm{Ar}$ main peak intensity ratio, and high $\mathrm{Mg}$ content of calcite in several cases was estimated visually by the shift of the peak to dolomite (3.00-3.01 A), with no further calculations because of insufficient amount of the material. To demonstrate the reliability of the data, we provide values of absolute intensity (I) of reflection peaks. If the intensities of calcite ( $\left.\mathrm{I}_{\text {calc }}\right)$ and/ or aragonite $\left(\mathrm{I}_{\text {arag }}\right)$ major peaks are close to the background intensity $\left(\mathrm{I}_{\mathrm{bgr}}=5-6\right)$, the calculations of calcite/aragonite ratio for corresponding sample are unreliable.

Because most spirorbins are small, the quantity of powder obtained from a single tube often falls somewhere around the edge of the diffractometer resolution ability. To improve data reliability, in most cases we had to analyze calcitearagonite ratios averaged over a set of specimens. Yet, for some species the quantity of available material was insufficient even for such kind of analysis, so our mineralogical study covered only about $80 \%$ of species studied with SEM. Exact quantity of powder studied in each case differed depending on material availability for each species, thus affecting reliability of analysis for each case. For several species, two independent samples were taken: one based on a single specimen, another averaged over several specimens.

For illustration of tube morphology spirorbins tubes were photographed with a digital camera DFC295 under microscope Leica MZ6 by method of sequential layers. Helicon Focus software was used for merging differently focused images.

\section{Results}

\section{Tribe Paralaeospirini Knight-Jones, 1978}

Diagnosis. The egg-string is incubated in the parent's tube, being neither attached to the tube wall, nor to the body of a parent; accordingly, the only type of operculum throughout life time is an endplate, usually with a talon. Other characteristic features are: 1) narrow saw to rasp-shaped thoracic uncini, each starting with one row of large teeth posteriorly and ending with 3 rows of large teeth in front of blunt anterior peg; 2) abdominal uncini distributed asymmetrically: they are absent from the convex side of body, or present only on last chaetigers; 3) abdominal chaetae are flat geniculate, pennant-shaped (blade width decreases gradu- 
ally towards tip), usually with a thick projecting heel; the length of their blade is no longer than blade length of largest collar chaetae; 4) abdominal companion capillary hooked chaetae may be present only on last abdominal chaetigers; 5) larvae are without white attachment glands.

Remarks. The tribe unconditionally contains the only genus Paralaeospira Caullery et Mesnil, 1897. Genera Metalaeospira Pillai, 1970 and Eulaeospira Pillai, 1970 initially included in Paralaeospirini (Knight-Jones, Fordy, 1979; Knight-Jones P. et al., 1979) incubate embryos in the sac attached to the body, have brush-type abdominal chaetae and therefore, belong to the tribe Romanchellini (Knight-Jones P., KnightJones E.W., 1994).

Two monotypic genera Anomalorbis Vine, 1972 and Crozetospira Rzhavsky, 1997, with yet unknown incubation method, were originally placed within Paralaeospirini provisionally. Therefore, only tubes of Paralaeospira are discussed here, while tube ultrastructures of Crozetospira dufresnei Rzhavsky, 1997 will be described in subsequent papers, among other spirorbins of uncertain tribe attribution. Material on Anomalorbis was not available for our study.

Distribution. Mostly south temperate belt and Antarctic (Knight-Jones P., Knight-Jones E.W., 1984), though P. malardi is known only from boreal waters of north-eastern Atlantic (Knight-Jones P., Knight-Jones E.W., 1977; Knight-Jones P. et al., 1991).

\section{7}

Genus Paralaeospira Caullery et Mesnil,

Type species: Spirorbis (Paralaeospira) aggregata Caullery et Mesnil, 1897

Diagnosis. Sinistral tubes; margins of collar and thoracic membranes not fused over thoracic groove; large collar chaetae bent, with basal fins and distal serrated blades without cross-striation; simple limbate and sickle chaetae in $3^{\text {rd }}$ thoracic fascicles; four thoracic chaetigers.

Composition. The genus includes 10 species, four of which are covered in the present study.

Distribution. As for the tribe.

\section{Paralaeospira claparedei Caullery et Mesnil, 1897}

Fig. 2A-D.

For descriptions see Caullery, Mesnil, 1897: 204, P1. VIII, fig. 10 (as "Spirorbis (Paralaeospira) claparedei"); Harris, 1969: 142-145, fig. 4 a-1 (as "Spirorbis claparedei").

Material examined. Two specimens were examined with SEM in longitudinal sections (IPEE No. 3/2562, Magellan Strait, shallow water, on Macrocystis fronds). Mineralogy was analyzed by a single tube from the same sample. Outer tube morphology was illustrated for specimens from the same sample and from IPEE No. 1/2536 (Prince Edward Islands, depth $110 \mathrm{~m}$, on bryozoans).

Tube morphology. Tubes are sinistral, planospiral (Fig. 2A) or with overlapping coils (Fig. 2B), tube mouths may be facing upward from substrate (Fig. 2C). Whorl diameter is up to $2.5 \mathrm{~mm}$. Tube walls are thin and fragile, white opaque or somewhat transparent, non-porcellanous or slightly porcellanous. Tube surface is smooth, unsculptured; specimens attached to algae may produce peripheral flange (Fig. 2B).

Tube ultrastructures. Wall is unilayered, with irregularly oriented prismatic (IOP) structure. Two studied specimens have slightly different appearance of crystals in tube wall. One demonstrates isometric small crystals $0.5-0.75$ $\mu \mathrm{m}$ long mixed with some cement in inner part of the wall, gradually turning to slightly elongated angular crystals up to $1-2 \mu \mathrm{m}$ long and $0.7-$ $1.2 \mu \mathrm{m}$ wide in the outer part; total wall width in the same section is $32-35 \mu \mathrm{m}$. A section obtained for another specimen (Fig 2D) shows mostly elongated crystals of $2-3 \mu \mathrm{m}$ long mixed with a small amount of cement, except for innermost zone, where crystals are small and isometric; corresponding total wall width is $35-40 \mu \mathrm{m}$. Crystal shapes are angular in both studied specimens. Distinct growth lamellae are absent, but at least one area with unclear orientation of elongated crystals along growth lines was observed (Fig. 2D). Inner organic lining is thin (not exceeding $1 \mu \mathrm{m}$ ).

Tube mineralogy. $100 \%$ calcite $\left(\mathrm{I}_{\text {calc. }}=32\right)$ with high $\mathrm{Mg}$ content. 


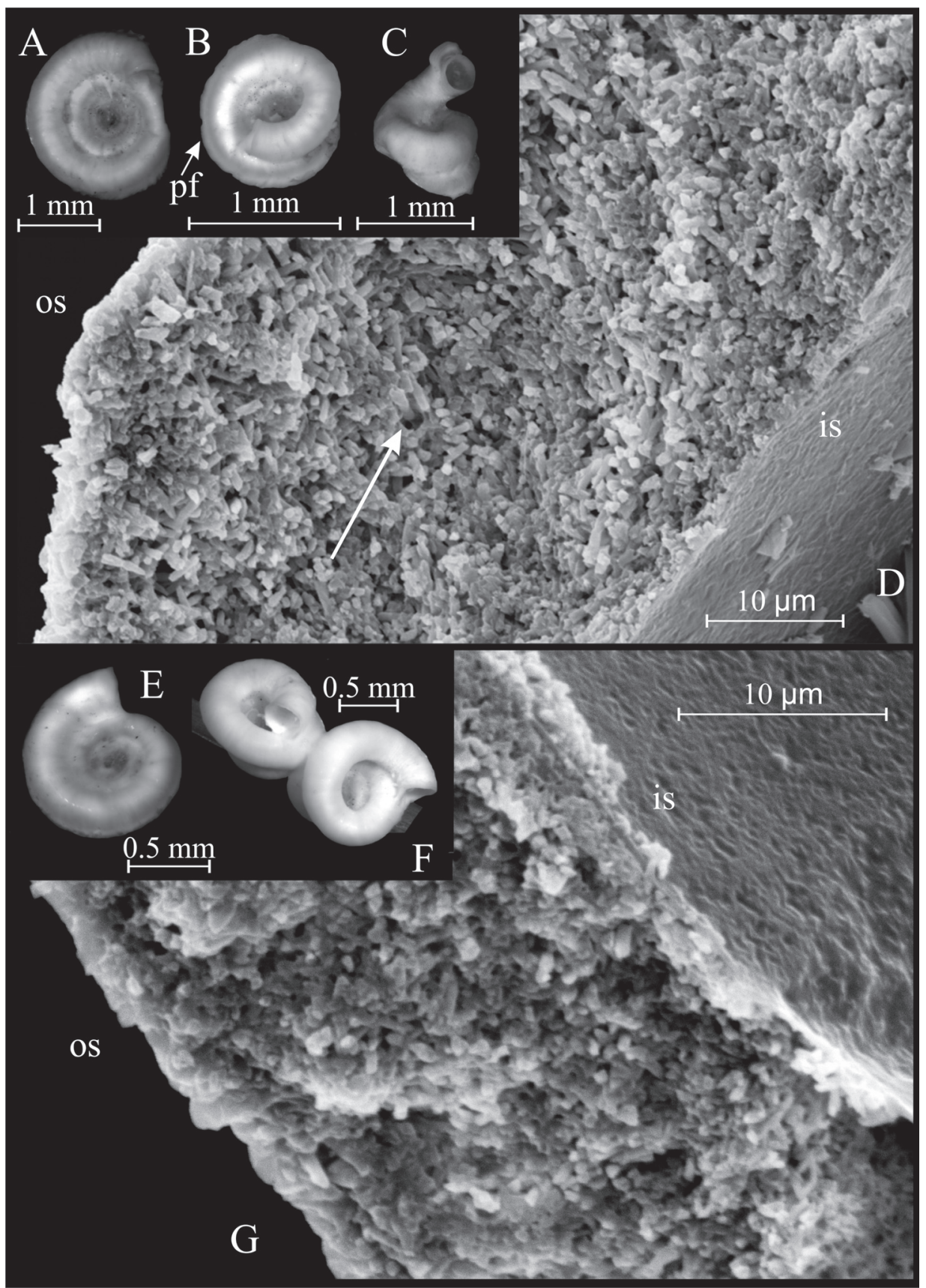

Fig. 2. A-D - Paralaeospira claparedei. A-C - tubes: A - planospiral tube (IPEE No. 3/2562), B tube with overlapping coils and $\mathrm{C}$ - tube with mouth faced upward from substrate (IPEE No. 1/2536); $\mathrm{D}$ - longitudinal wall section at the external side of spiral showing IOP ultrastructure, note smaller crystals near the internal side of the wall, probably representing inner layer of oriented prismatic crystals; $\mathrm{E}-\mathrm{G}-$ Paralaeospira levinseni. E-F - tubes: E - planospiral tube (IPEE No. 1/2398), F — tubes with overlapping coils (IPEE No. 2401); G - longitudinal wall section at the external side of the coil, showing IOP structure. 
Distribution. Southern Atlantic and Atlantic sector of Southern Ocean: Magellan Strait (Knight-Jones P., Knight-Jones E.W., 1991) and Cape Horn (Caullery, Mesnil, 1897), probably Falkland and South Orkney Isles (KnightJones P., Knight-Jones E.W., 1984). Southern Indian Ocean: Kerguelen Isles (Harris, 1969); Prince Edward and Crozet Isles (Rzhavsky, 1998).

Ecology. The species is known from the shallow water (probably intertidally) up to 110 $\mathrm{m}$ deep. It lives on brown algae, seaweeds, shell fragments, and bryozoans.

Remarks. $P$. claparedei is known only from several records. Its tube morphology is similar to that of another rare species from the Southern Hemisphere, $P$. patagonica that may be the same species as $P$. claparedei (see Remarks for $P$. patagonica).

\section{Paralaeospira levinseni Caullery et Mesnil, 1897}

Fig. 2E-G.

For descriptions see Caullery, Mesnil, 1897: 204, P1. VIII, fig. 14 (as "Spirorbis (Paralaeospira) levinseni"); Knight-Jones P., Walker, 1972: 33-35, Fig. 1 a-n, 2 a, b; Vine, 1977: 17-20, Fig. 2 e, 6 c, 8 a-j.

Material examined. Two specimens were examined with SEM in longitudinal sections (IPEE No. 1/2398, South Georgia Island, upper sublittoral zone, on the Macrocystis thallus). Mineralogical composition was analyzed in one sample averaged over 3 tubes from the same sample. Outer tube morphology illustrated using specimens from IPEE No. 1/2398, and IPEE
No. 2/2401 (Bunger-Hills, Mawson Sea, depth 20-50 m, on the sea urchin spines).

Tube morphology. Tubes are sinistral, planospiral (Fig. 2E) either with overlapping coils (Fig. 2F) or last whorl can be evolute (Vine, 1977, Fig. 8a). Whorl diameter is up to $2.5 \mathrm{~mm}$; tube walls are thin and fragile, white opaque or slightly transparent, with smooth non-porcellanous or slightly porcellanous surface; unsculptured or rarely with vestigial longitudinal keel. Dense aggregations are often formed as a result of larval gregarious settlement on adult tubes (see Knight-Jones P., Walker, 1972, Fig. 1a, 2a, b; Vine, 1977, Fig. 8a).

Tube ultrastructures. Wall is unilayered with irregularly oriented prismatic (IOP) structure. Crystal average size and appearance is more or less uniform throughout wall, but changes slightly from the inner to the outer zones. Crystals in the inner half of the wall are mostly isometric to slightly elongated (Fig. $2 \mathrm{G})$, small $(0.3-1 \mu \mathrm{m})$. Outer half of the wall contains relatively more elongated larger crystals $\sim 1-1.2 \mu \mathrm{m}$, rarely up to $2 \mu \mathrm{m}$ long; corresponding wall thickness is 20 $\mu \mathrm{m}$. No distinct growth lamellae are visible. Inner organic lining is thin $(0.5 \mu \mathrm{m}$ or less $)$.

Tube mineralogy. $100 \%$ calcite $\left(\mathrm{I}_{\text {calc. }}=115\right)$ with high $\mathrm{Mg}$ content.

Distribution. The species is widely distributed in the Southern Hemisphere. Known throughout the South American coast from Peru in the Pacific to Uruguay in Atlantic; off many islands in Southern, South Atlantic, and South Indian Oceans; south coasts of Africa and Australia, New Zealand and Antarctica coasts (Knight-Jones P., Knight-Jones E.W., 1984).

\footnotetext{
Abbreviations: os — outer surface, is — inner surface, $\mathrm{pf}$ - peripheral flange. Large arrow indicates tube growth direction.

Рис. 2. A-D - Paralaeospira claparedei. A-C - трубки: А - планоспиральная трубка (IPEE No. 3/ 2562), В - трубка с налегающими оборотами, C — трубка с устьем, приподнятым над субстратом (IPEE No. 1/2536); D — продольное сечение стенки трубки с внешней стороны спирали, демонстрирующее ультраструктуру из хаотически ориентированных призматических кристаллов; заметно, что возле внутренней стороны стенки кристаллы имеют более мелкий размер, возможно, они представляют внутренний слой из призматических кристаллов, ориентированных более-менее параллельно поверхности; E-G - Paralaeospira levinseni. E-F - трубки: Е - планоспиральная трубка (IPEE No. 1/2398), F — трубки с налегающими оборотами (IPEE No. 2401); G — продольное сечение стенки на внешней стороне оборота, демонстрирующее структуру из хаотически ориентированных призматических кристаллов.

Условные обозначения: os — наружная поверхность, is - внутренняя поверхность, pf — периферийный фланг. Большая стрелка показывает направление роста трубки.
} 
Ecology. The species lives from the intertidal zone up to about $50 \mathrm{~m}$ deep, where it occupies stones, algae, ascidians, other spirorbin tubes, and sea urchin spines.

\section{7 \\ Paralaeospira malardi Caullery et Mesnil,} Fig. 3A-F.

For descriptions see Caullery, Mesnil, 1897: 205, Pl. VIII, fig. 11a, b (as "Spirorbis (Paralaeospira) malardi"); Knight-Jones P., Knight-Jones E.W., 1977: 474-476, Fig. $7 \mathrm{~A}-\mathrm{H}$.

Material examined. Two specimens were examined with SEM in longitudinal sections (IPEE No. 1/2558, English Channel, depth 1-5 $\mathrm{m}$, on stones). Outer tube morphology was illustrated for a specimen from the same sample.

Tube morphology. Tubes are sinistral, planospiral; up to $2.0 \mathrm{~mm}$ in whorl diameter; white opaque with distinctly porcellanous smooth surface, bearing an obtuse median keel often terminating as a tooth-like projection over tube mouth (Fig. 2A); juveniles usually lack keel. Tube aggregations are unknown.

Tube ultrastructures. Tube wall is visually unilayered with irregularly oriented prismatic (IOP) structure consisting of two distinct zones. Outer and middle parts of the wall are made of isometric crystals mixed with cement (Fig. 3B). Crystal size range is $0.5-3 \mu \mathrm{m}$, typically about $0.5-1 \mu \mathrm{m}$; corresponding wall width is $40 \mu \mathrm{m}$ (Fig. 3C, D). Crystals of the innermost wall part form a thin layer, often not clearly visible in longitudinal sections and consisting of acicular crystals $3-5 \mu \mathrm{m}$ long and $0.5-0.8 \mu \mathrm{m}$ wide, lying more or less parallel to the lumen with no further orientation. A longitudinal section made near the tube base shows elongated acicular crystals similar to those of the innermost zone by shape, but sometimes slightly longer, up to 5 $\mu \mathrm{m}$ long (Fig. 3E). Indistinct growth lamellae marked by some difference in amount of cement along smallest discernible growth lines can be observed in all sections. Inner organic lining is thick, about 5-6 $\mu \mathrm{m}$ (Fig. 3C).

Tube mineralogy. Not studied due to insufficient material.

Distribution. This is the only Paralaeospira known from the Northern Hemisphere. It is recorded from north-east Atlantic off the British, Irish, French and Spanish coasts (KnightJones P., Knight-Jones E.W., 1977).

Ecology. The species lives from the lower intertidal zone to the depths of about $25 \mathrm{~m}$, where it usually occupies stones, sometimes mollusk shells and decapod carapaces, rarely can be found on algae.

\section{Paralaeospira patagonica Caullery et Mesnil, 1897}

Fig. 4A-I.

For descriptions see Caullery, Mesnil, 1897: 205206, Pl. VIII, fig. 12 (as “Spirorbis (Paralaeospira) patagonicus"); Harris, 1969: 162, fig. 15a-1 (as "Spirorbis patagonicus").

Material examined. Two specimens were examined with SEM in longitudinal sections (IPEE No. 2/2575, Swakopmund, Namibia, low intertidal zone, on undersides of stones). Mineralogical composition was analyzed by a single tube from the same sample. Outer tube morphology was illustrated for specimens from the same sample and from IPEE No. 1/2561 (Kerguelen Island, Southern Indian Ocean, on algae, depth unknown).

Tube morphology. Tubes are sinistral, planospiral (Fig 4A, B) or often with overlapping coils (Fig. 4C); up to $2.5 \mathrm{~mm}$ in whorl diameter; thin-walled, fragile, white opaque; with smooth non-porcellanous or slightly porcellanous sur-

Рис. 3. Paralaeospira malardi: А - трубка с хорошо развитым серединным килем и блестящей фарфоровидной поверхностью; В-Е - ультраструктуры трубок, экземпляр № 1 [В - продольное сечение наружной стороны оборота; C — внутренняя органическая мембрана трубки, также заметны прилипшие к ней призматические кристаллы $\mathrm{CaCO}_{3}$; D - внутренняя поверхность трубки (органическая мембрана удалена), демонстрирующая уплощенную поверхность с удлиненными кристаллами); Е — кристаллы непосредственно под органической мембраной]; F — экземпляр № 2, продольное сечение наружной части последнего оборота).

Условные обозначения: os - наружная поверхность, is - внутренняя поверхность, iol — внутренняя органическая мембрана. 


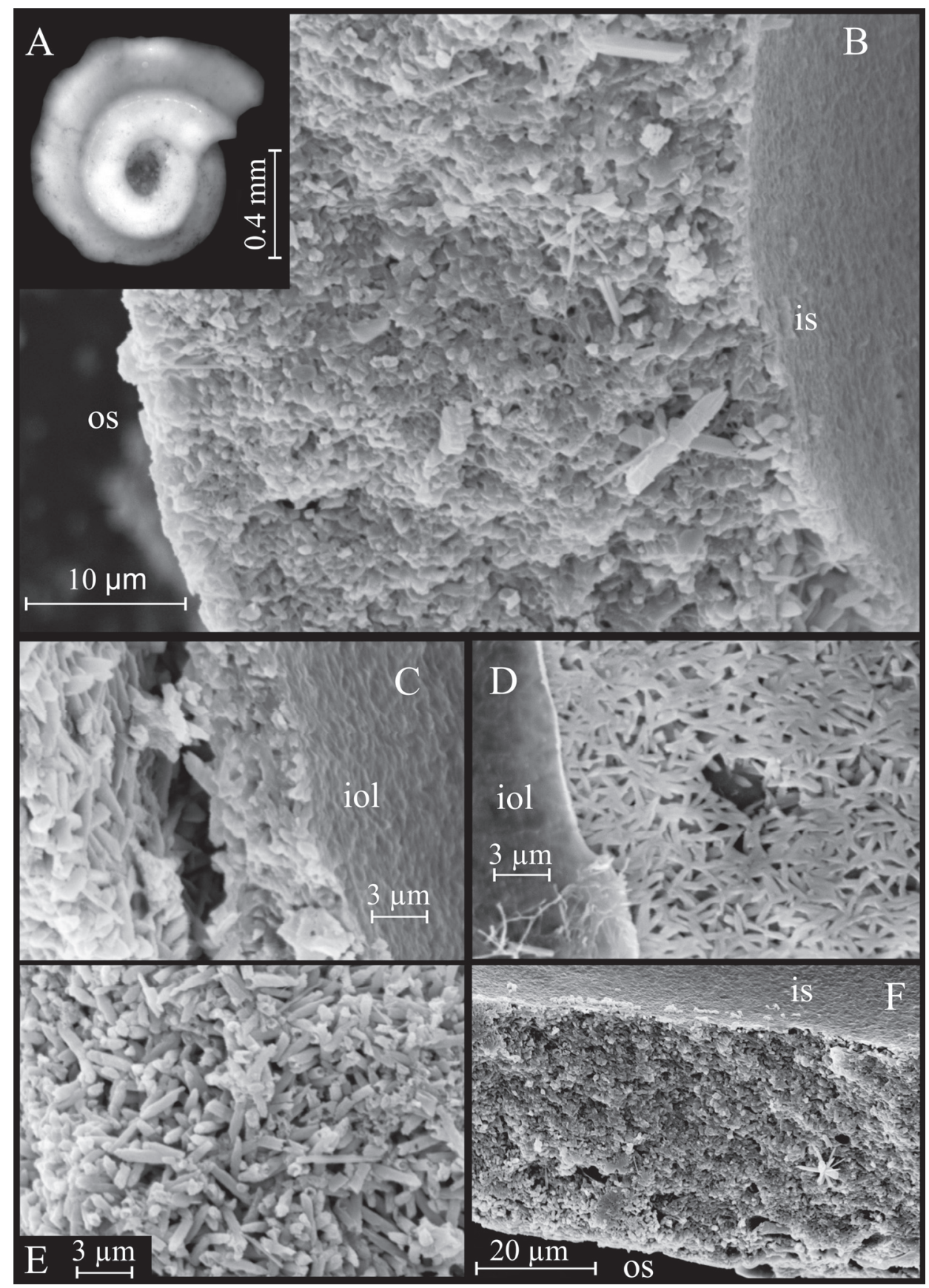

Fig. 3. Paralaeospira malardi: A - tube with well-developed median keel and porcellanous surface; B-E tube ultrastructures. Specimen 1 [B - longitudinal section of the external side of the coil; $\mathrm{C}$ - inner organic lining, also showing embedded prismatic $\mathrm{CaCO}_{3}$ crystals; $\mathrm{D}$ - inner surface of the tube (organic layer removed) showing flattened surface made of elongated crystals; $\mathrm{E}$ - crystals near the lumen]; $\mathrm{F}$ - specimen 2 , longitudinal section of the external side of the last whorl.

Abbreviations: os — outer surface, is — inner surface, iol — inner organic lining. 


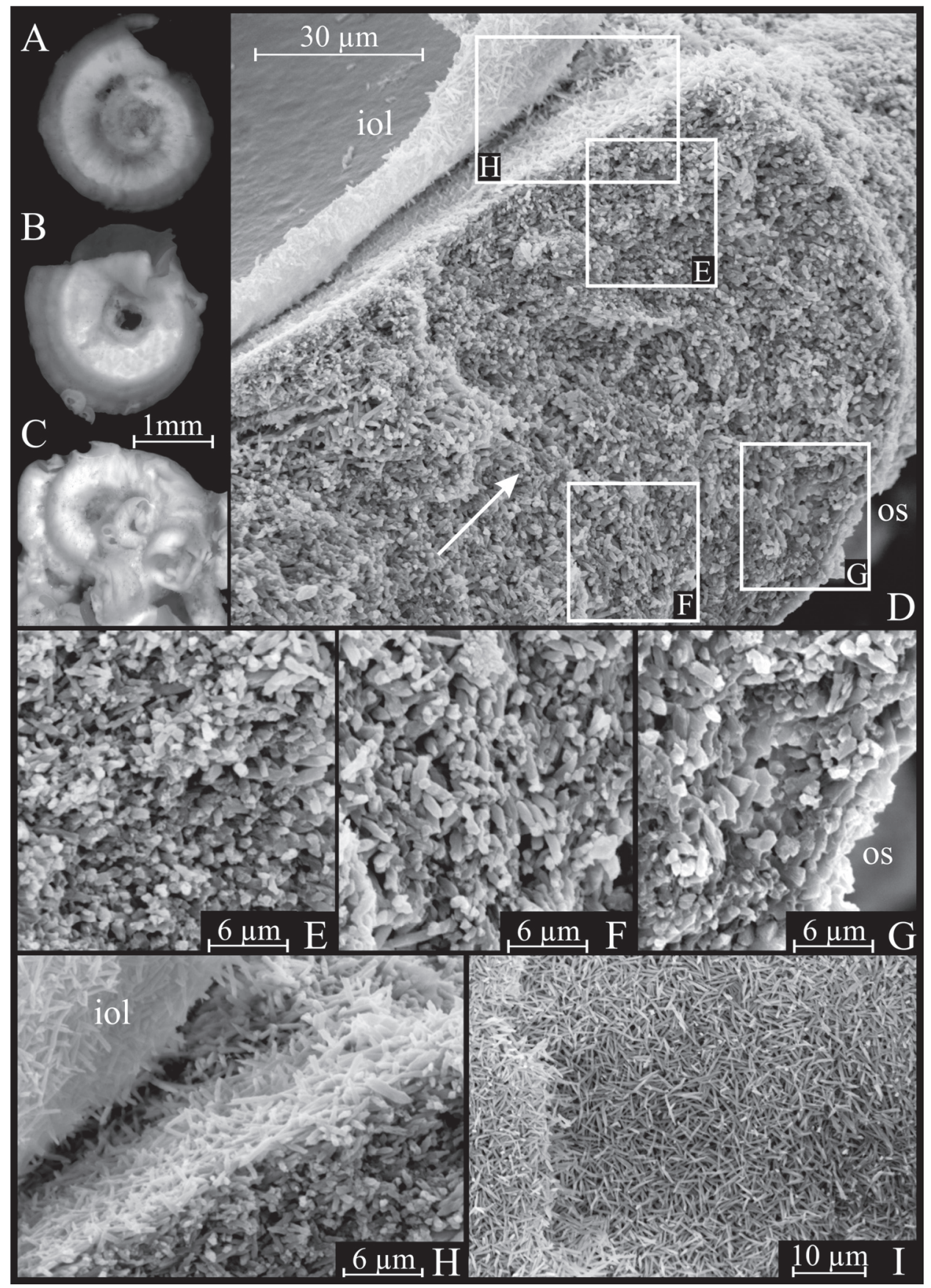

Fig. 4. Paralaeospira patagonica. A-C - tubes: A - planospiral tube with a single vestigial keel and pronounced growth lines, B - planospiral tube with two vestigial keels (IPEE No. 1/2561), C — aggregation of unsculptured tubes with overlapping coils (IPEE No. 2/2575); D-I - tube ultrastructures: D - general view of longitudinal section near the tube mouth, $\mathrm{E}-\mathrm{G}$ - details of different parts of the wall, $\mathrm{H}$ - contact of the mineral wall with inner organic lining, note the adhesion of calcite crystals to the organic lining, Itube surface just under the inner organic lining. 
face (Fig. 4C), unsculptured, or bearing one or two vestigial keels (Fig. 4A, B); dense aggregations are often formed (Fig. 4C).

Tube ultrastructures. Wall is unilayered, with IOP ultrastructure represented by slightly elongated to distinctly elongated loosely packed crystals $1-3 \mu \mathrm{m}$ long; corresponding wall width is $70 \mu \mathrm{m}$ (Fig. 4D). Crystals are gradually becoming less elongated and more isometric (Fig. 4G) towards external tube surface. Middle part of the wall contains numerous smaller isometric crystals of uniform size and interspersed among larger elongated crystals (Fig. 4E, F). Innermost part of the wall is represented by acicular crystals (4-6 $\mu \mathrm{m}$ long and $\sim 0.5 \mu \mathrm{m}$ wide) lying parallel to the lumen (Fig. 4H, I). Growth lamellae are distinct and marked by variations of crystal size. Parabolic lamellae symmetrical, their axes are located centrally in the wall. Inner organic lining is 3-6 $\mu \mathrm{m}$ wide.

Tube mineralogy. 100\% calcite $\left(\mathrm{I}_{\text {calc }}=73\right)$. Calcite has high $\mathrm{Mg}$ content (main peak at 34.61 20).

Distribution. The species is known through the south coast of Africa from Namibia to Port Elisabeth, Republic of South Africa; off the south of Chile and some islands of South Atlantic and Atlantic sector of Southern Ocean (Knight-Jones P., Knight-Jones E.W., 1984); off some islands of Southern Indian Ocean (Rzhavsky, 1998).

Ecology. This is a shallow water species living in the intertidal and upper sublittoral zones, but exact bathymetric data are absent. It occupies bryozoans, algae, and undersides of stones.
Remarks. $P$. patagonica is known only by several records and is similar in external tube morphology as well as in opercular and chaetal structure to another rare species from Southern Hemisphere, $P$. claparedei, which in our opinion may be a synonym of the $P$. patagonica. General appearance of wall ultrastructures in these two species also shows high similarity, like in all studied Paralaeospirini. Although in $P$. claparedei we have not observed an inner layer made of oriented elongated crystals, similar to that found in P. patagonica, this may be due to scarcity of studied material. Additional morphological studies are needed to clarify the relationship between these two species; here we consider them both valid.

\section{Tube morphology of species not covered with the SEM study}

External tube morphology markedly varies among six species of Paralaeospira not covered with SEM study. Two of these species, $P$. pseudotenuis Rzhavsky, 1997 and P. sicula Knight-Jones et Knight-Jones, 1994, were examined by the second author. General morphology of $P$. pseudotenuis tube is similar to those of P. claparedei, P. levinseni, and P. patagonica (Fig. 5A, B). Tubes of $P$. sicula are usually evolute and have quadrangular cross-section with very characteristic sharp keels (Fig. 5C, D).

Tube morphology of other species of Paralaeospira is known from literature only. P. monacantha (Augener, 1923) has tubes similar to those of $P$. claparedei, P. levinseni, and $P$. patagonica and often produce aggregations (Fig. 5E). P. parallela Vine, 1977, like $P$. malardi, is

\footnotetext{
Abbreviations: os - outer surface, is - inner surface, iol — inner organic lining. Large arrow indicates the direction of tube growth.

Рис. 4. Paralaeospira patagonica. A-C - трубки: А — планоспиральная трубка с одним зачаточным продольным килем и выраженными линиями нарастания, В - планоспиральная трубка с двумя зачаточными продольными килями (IPEE № 1/2561), C — агрегация нескульптурированных трубок с налегающими оборотами (IPEE № 2/2575); D-I - ультраструктуры трубок: D - общий вид продольного сечения близ устья трубки; $\mathrm{E}-\mathrm{G}$ - различные участки стенки, более крупно, $\mathrm{H}$ контактовая зона стенки и внутренней органической мембраны, хорошо заметно прилипание кристаллов кальцита к мембране, I- внутренняя поверхность трубки и облик кристаллов непосредственно под мембраной.

Условные обозначения: os - наружная поверхность, is - внутренняя поверхность, iol - внутренняя органическая мембрана. Большая стрелка показывает направление роста трубки.
} 


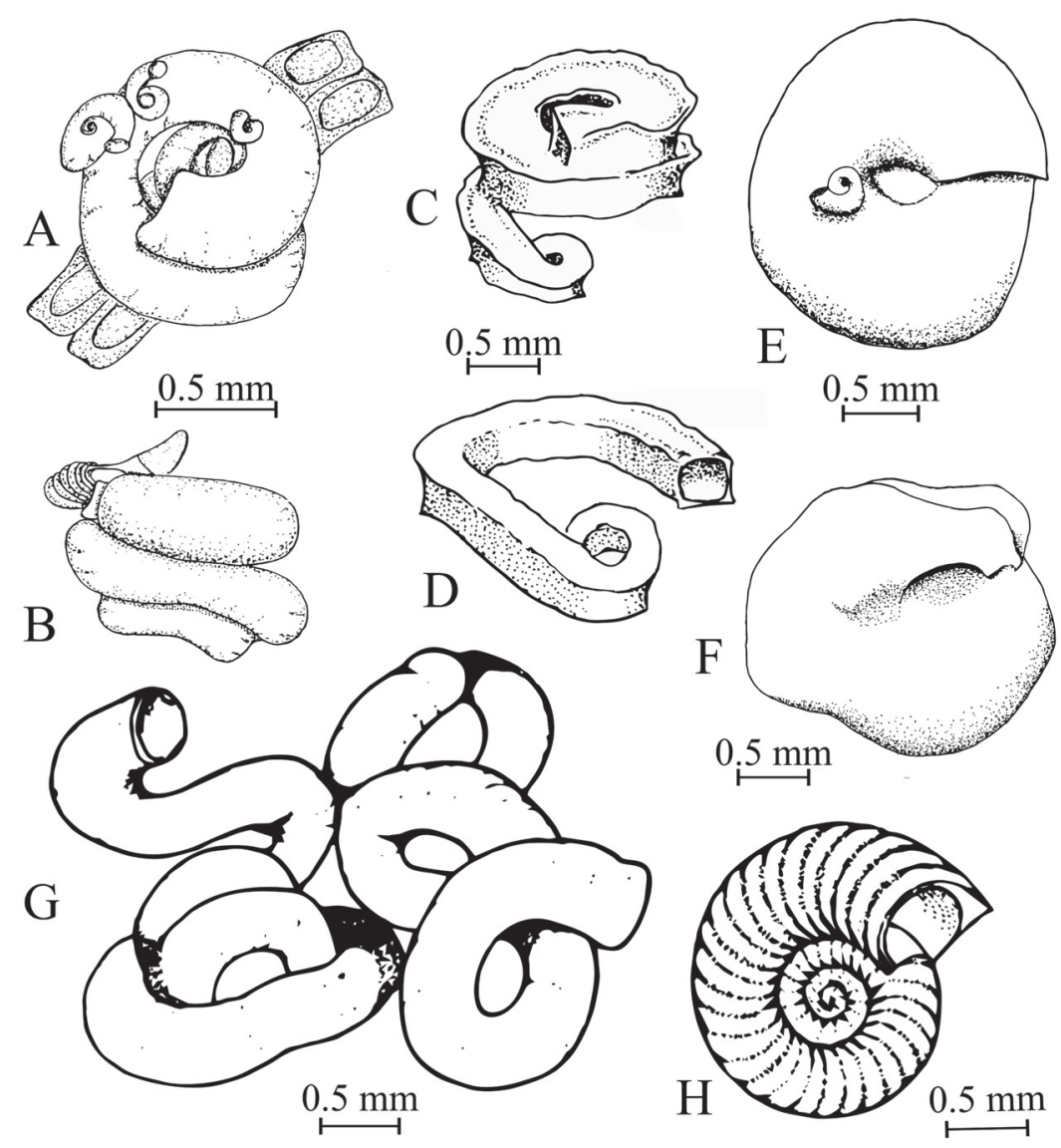

Fig. 5. Tubes of Paralaeospirini species not covered in the present study. A, B - Paralaeospira pseudotenuis (from Rzhavsky, 1997); C, D - P. sicula (from Knight-Jones, Knight-Jones, 1994); E - P. monacantha (from Vine, 1977); F — P. parallela (from Vine, 1977); G — P. aggregata (from Harris, 1969); H — P. adeonella (from Day, 1963).

Рис. 5. Морфологическое разнообразие трубок представителей Paralaeospirini, которые не изучались авторами в ходе настоящего исследования. А, В - Paralaeospira pseudotenuis (из Rzhavsky, 1997); C, D - P. sicula (из Knight-Jones, Knight-Jones, 1994); Е — P. monacantha (из Vine, 1977); F — P. parallela (из Vine, 1977); G - P. aggregata (из Harris, 1969); Н — P. adeonella (из Day, 1963).

always solitary and has planospiral hard tubes that are, however, non-porcellanous and lack longitudinal keel(s). The characteristic feature of the $P$. parallela tube is the mouth completely covering the preceding whorl (Fig. 5F). P. aggregata (Caullery et Mesnil, 1897), like $P$. malardi, has porcellanous tubes, but unlike $P$. malardi, it lacks any longitudinal sculpture. Besides, tubes of $P$. aggregata are never planospiral, coils always overlap and the last coil is usually straightened. This species always forms dense aggregations (Fig. 5G).P. adeonella (Day, 1963) known only from its original description, has thick-walled, hard and vitreous tubes with well-pronounced transverse ridges (Fig. 5H). Similar tubes are not known for other Paralaeospira spp. and are more common in the genus Protolaeospira from tribe Romanchellini. Unfortunately, data on incubation method and morphology of abdominal chaetae that could have helped to clarify systematic position of $P$. adeonella, were not provided. 


\section{Discussion}

Patterns and variations. Although three of the four species described herein have similar tube ultrastructures, variability in tube morphology among all species of Paralaeospira is very high. The only stable characters are the coiling direction (always sinistral) and the absence of or small number of keels (usually one, rarely two). Mineralogical tube composition in all three studied Paralaeospira species was purely calcitic, and all studied species had the same ultrastructural type (IOP) composed of slightly elongated to isometric angular crystals lying loosely with no clear orientation of their long axes (Table 2).

P. malardi shows distinct characteristics (wall consisting mostly of isometric crystals with high content of cement, probably of organic nature), allowing its recognition among studied Paralaeospira spp. by ultrastructure only. Tube morphology of this species also differs from those of other studied species by being more thick-walled, always planospiral, white opaque with distinctly porcellanous surface, and bearing an obtuse median longitudinal keel that often terminates as a tooth-like projection over the mouth. Opaque tube appearance is of $P$. malardi is probably the result of high content of cement, which is more abundant, than in other studied species. Other examined species of Paralaeospira are characterized by relatively thin-walled tubes, sometimes even semi-transparent, with non-porcellanous or slightly porcellanous surfaces; coiling can vary from planospiral to overlapping, or last coil can even be evolute; longitudinal keel, if present, is vestigial. Additionally, all these species may form aggregations, whereas $P$. malardi is always solitary. P. malardi is also isolated biogeographically as it is the only species of the genus Paralaeospira known from the Northern Hemisphere, while others are restricted to the Southern Hemisphere. Nevertheless, general appearance of tube ultrastructures is still very similar among all studied Paralaeospirini.

Inner organic lining in $P$. malardi and $P$. patagonica is underlain by a thin layer of acic- ular crystals (length up to $5 \mu \mathrm{m}$, width $0.3-0.5$ $\mu \mathrm{m})$, lying parallel to the lumen with no further orientation. A similar thin layer built of acicular crystals was also observed for the non-spirorbin serpulid Ficopomatus enigmaticus (Fauvel, 1923) by Aliani et al. (1995). Such a layer was not mentioned for any species studied by Vinn et al. (2008a), probably due to different methods of sample preparation, which always included treating by aggressive agents. The nature of this "layer" is probably mechanical arrangement of elongated rice grain-shaped crystals near the lumen during the tube formation, and therefore, its presence is not indicative of close phylogenetic relationship. The presence of inner layer with acicular crystals still cannot be excluded for two other species of Paralaeospira (P. levinseni and P. claparedei), but this needs to be clarified with new material.

Comparison with other Serpulidae. The unilayered IOP walls found in Paralaeospira are very common among non-spirorbin serpulids (Vinn et al., 2008a), and therefore, ultrastructures are not diagnostic. It is easy to distinguish Paralaeospira from all these taxa by external morphology, in particular, clockwise tube coiling combined with small size. Detailed comparisons with other spirorbin tribes will be provided in the subsequent parts of the present series.

Phylogenetic significance. Unilayered tube with IOP ultrastructure of Paralaeospira is very similar to IOP ultrastructures described for serpulids of "clade B" sensu Kupriyanova et al. (2009). This clade includes genera such as Filograna, Salmacina, Protis, Vermiliopsis, Metavermilia, Protula, and Chitinopoma. These genera form a sister-group to monophyletic spirorbins (Kupriyanova et al., 2006, 2009). Given that in many spirorbins ultrastructures appear more derived than those of Paralaeospirini (Ippolitov, Rzhavsky, 2008), the hypothesis that Paralaeospirini having simplest method of embryos incubation is the most primitive spirorbin group is well supported. Therefore, our data confirm a closer relationship of primitive spirorb- 


\begin{tabular}{|c|c|c|c|c|c|c|}
\hline 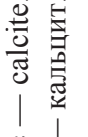 & \multirow{4}{*}{ 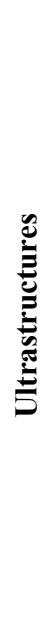 } & 苞 & 荅 & 宐 & 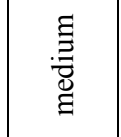 & 菅 \\
\hline 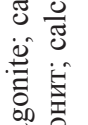 & & 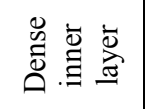 & ‡ & ‡ & ‡ & ‡ \\
\hline 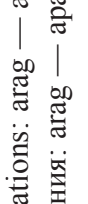 & & 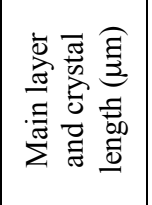 & 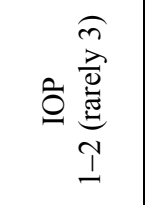 & อิ ฺ & 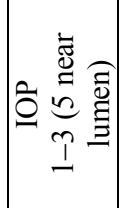 & 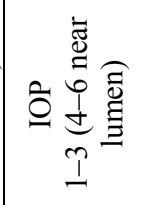 \\
\hline $\begin{array}{l}\frac{5}{5} \\
\frac{\pi}{M} \\
0 \\
0 \\
0 \\
0\end{array}$ & & 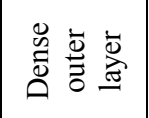 & ‡ & ‡ & 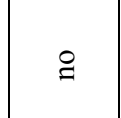 & $\stackrel{8}{g}$ \\
\hline 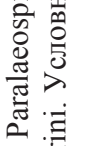 & \multirow{2}{*}{ 党 } & 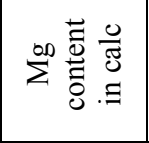 & . & .50 & 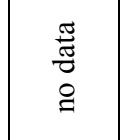 & $\stackrel{500}{=}$ \\
\hline 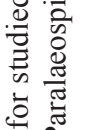 & & कृष & $\stackrel{8}{\stackrel{8}{0}}$ & $\stackrel{8}{\stackrel{8}{0}}$ & 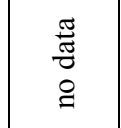 & $\frac{8}{0}$ \\
\hline 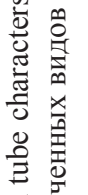 & \multirow{4}{*}{ 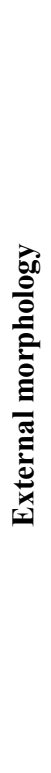 } & $\begin{array}{l}\mathscr{\mathscr { J }} \\
\stackrel{\mathscr{\Xi}}{\Xi}\end{array}$ & 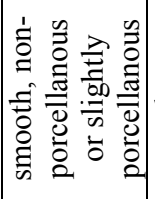 & 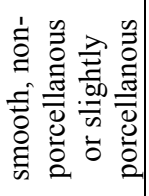 & 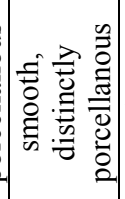 & 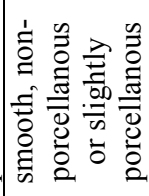 \\
\hline 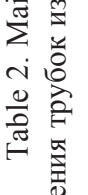 & & 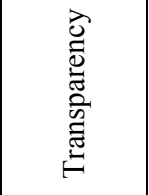 & 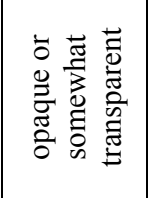 & 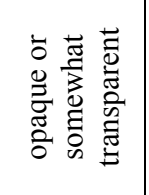 & 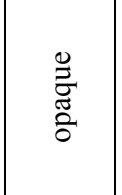 & 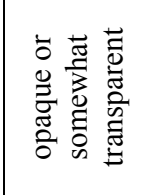 \\
\hline 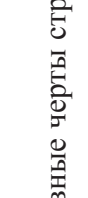 & & 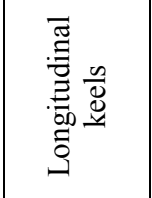 & 0 & 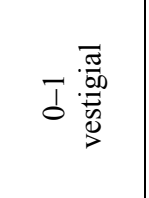 & 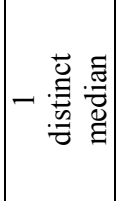 & 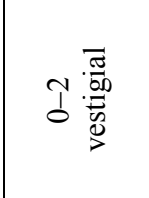 \\
\hline 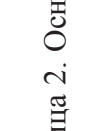 & & 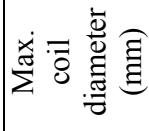 & $\stackrel{n}{n}$ & $\stackrel{n}{\sim}$ & $\stackrel{\circ}{\sim}$ & $\stackrel{n}{n}$ \\
\hline ర్రే & & 苋 & 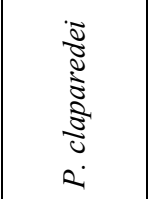 & 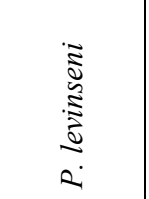 & 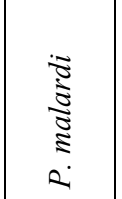 & $\begin{array}{c}0 \\
0 \\
0 \\
0 \\
0 \\
0 \\
0 \\
0 \\
0 \\
0\end{array}$ \\
\hline
\end{tabular}


ins to "clade B", rather than to other serpulids. However, tubes belonging to the listed genera of "clade B" are characterized by predominantly aragonite mineralogy with only little calcite (Bornhold, Milliman, 1973; Vinn et al., 2008a; Smith et al., 2013). The only species that may have calcitic tubes is Filograna implexa (Berkeley, 1835) (see discussion in Vinn et al., 2008a: 646).

Aragonitic mineralogy of serpulid tubes is interpreted as the most ancient (Vinn, Mutvei, 2009) according to the well-accepted hypothesis that seawater chemical environment of Late Carboniferous - Early Jurassic interval, when true serpulids first appeared in paleontological record, was more suitable for aragonite than for calcite precipitation. In frame of this hypothesis, first spirorbins, which appear later in the "calcitic" seas of the Late Jurassic - Early Cretaceous, should have calcitic tubes. This agrees with plesiomorphy of Paralaeospirini inferred from the simplest incubation method among Spirorbinae. However, why aragonitic serpulids should preserve their mineralogy through the "calcitic" epoch, as well as why calcitic serpulids would not switch their mineralogy to aragonite according to Recent environments, has no good explanation now.

Acknowledgements. We thank L.T. Protasevich, A.V. Kravtsev and R.A. Rakitov (PIN RAS), N.N. Surovenkova (IPEE RAS) and V.L. Kosorukov (GF MSU) for their kind help with technical part of the study. We are grateful to E.K. Kupriyanova (the Australian Museum, Sydney, Australia), who reviewed the manuscript and provided invaluable remarks and suggestions, greatly improving the paper. We also thank specialists and Institutions who donated materials to the collection of A.V. Rzhavsky. These are late Phyllis and Wyn Knight-Joneses (University of Wales, Swansea, UK); H. Zibrowius (formerly Station Marine d'Endoume, Marseille, France); Zoological Institute of Russian Academy of Sciences, Saint-Petersburg, Russia; A. V. Zhirmunsky Institute of Marine Biology of Far Eastern Branch of Russian Academy of Sciences; P.P. Shirshov Institute of
Oceanology, Russian Academy of Sciences and the Australian Museum, Sydney, Australia. We are also grateful to numerous collectors of the examined materials. The investigation was supported by the RFBR grant No. 14-05-31413 and RAS Presidium Program No. 28.

\section{References}

Aliani S., Bianchi C.N., de Asmundis C., Meloni R. 1995. Scanning electron microscope observations on the tube of the reef-forming serpulid Ficopomatus enigmaticus (Annelida, Polychaeta) // Bollettino di Zoologia. Vol.62. No.4. P.363-367.

Augener H. 1923. Polychaeten von den Auckland- und Campbell-Inseln // Videnskabelige Meddelelser fra Dansk naturhistorisk Forening i København. Vol.75. S.1-115.

Bandel K. 1986. The reconstruction of "Hyolithes kingi" as annelid worm from the Cambrian of Jordan // Mitteilungen aus dem Geologisch-Paläontologischen Institut der Universität Hamburg. H.61. S.35-101.

Berkeley M.J. 1835. Observations upon the Dentalium subulatum of Deshayes // Zoological Journal (London). Vol.5. No.20. P.424-427.

Bohnné Havas M. 1981. A Ditrupa cormea (L.) és konvergens formáinak szelekciója scanning elektronmikroszkóppal // Évi Jelentése a Magyar Állami Földtani Intézet. Az. 1979. Évröl. P.387-415.

Bornhold B.D., Milliman J.D. 1973. Generic and environmental control of carbonate mineralogy in serpulid (polychaete) tubes // Journal of Geology. Vol.81. No.3. P.363-373.

Bubel A., Stephens R.M., Fenn R.H., Feith P. 1983. An electron microscope, X-ray diffraction and amino acid analyses study of the opercular filament cuticle, calcareous opercular plate and habitation tube of Pomatoceros lamarckii Quatrefages (Polychaeta: Serpulidae) // Comparative Biochemistry and Physiology. Vol.74B. P.837-850.

Burchette T.P., Riding R. 1977. Attached vermiform gastropods in Carboniferous marginal marine stromatolites and biostromes // Lethaia. Vol.10. Iss.1. P.17-28.

Bush K. 1905. Tubicolous annelids of the tribes Sabellides and Serpulides from the Pacific Ocean // Harriman Alaska Expedition. Vol.12. P.169-355.

Carter J.G., Bandel K., de Buffrénil V., Carlson S.J., Castanet J., Crenshaw M.A., Dalingwater J.E., Francillion-Vieillot H., Géradie J., Meunier F.J., Mutvei H., de Riqlès A., Sire J.Y., Smith A.B., Wendt J., Williams A., Zylberberg L. 1990. Glossary of Skeletal Biomineralization // Carter J.G. (ed.). Skeletal Biomineralization: Patterns, Processes and Evolutionary Trends. Short Course in Geology. Vol.5. Pt.2. P.609671.

Caullery M., Mesnil F. 1897. Études sur la morphologie comparée et la phylogénie des espèces chez les 
Spirorbes // Bulletin scientifique de la France et de la Belgique. T.30. P.185-233.

Chamberlin R.V. 1919. The Annelida Polychaeta // Meoirs of the Museum of Comparative Zoology at Harvard College. Vol.48. P.1-514.

Claparède É. 1868. Les Annélides Chétopodes du Golfe de Naples // Mémoires de la Société de Physique et d'Histoire naturelle de Genève. Vol.19. No.2. P.313584.

Daudin F.M. 1800. Recueil de mémoires et de notes sor des espèces inéditis ou peu connues de mollusques, de vers et de Zoophytes. Paris. 50 p.

Day J.H. 1963. The Polychaete fauna of South Africa. Part 8. New species and records from grab samples and dredgings // Bulletin of the British Museum (Natural History). Vol.10. No.7. P.383-445.

Fabricius O. 1780. Fauna Groenlandica, systematice sistens, Animalia Groenlandiae occidentalis hactenus indagata, quoad nomen specificum, triviale, vernaculumque synonyma auctorum plurium, descriptionem, locum, victum, generationem, mores, usum, capturamque. Copenhagen \& Leipzig. 452 p.

Fauvel P. 1923. Un nouveau serpulien d'eau saumatre Merceriella n.g., enigmatica n.sp. // Bulletin de la Société Zoologique de France. Vol.47. P.424-430.

Fauvel P. 1927. Polychètes sedentaires. Addenda aux errantes, archiannélides, myzostomaires // Faune de France. T.16. 494 p.

Gee G.M., Knight-Jones E.W. 1962. The morphology and larval behavior of a new species of Spirorbis (Serpulidae) // Journal of the Marine Biological Association of the United Kingdom. Vol.42. No.3. P.641-654.

Goldfuss A. 1831. Petrefacta Germaniae. I. Divisio secunda: Radiariorum Reliquiae - Strahlenthiere der Vorwelt. Düsseldorf: Arnz \& Co. S.165-240.

Gravier C. 1907. Sur les Annélides Polychètes recueillies par l'Expédition Antarctique française (Terebelliens, Serpuliens) // Bulletin du Muséum d'Histoire Naturelle, Paris. Vol.13. P.46-52.

Harris T. 1969. Spirorbis species (Polychaeta: Serpulidae) from the South Atlantic // Discovery Reports. Vol.35. P.135-178.

Hove H.A., ten. 1984. Towards a phylogeny in serpulids (Annelida, Polychaeta) // Hutchings P.A. (ed.). Proceedings of the First International Polychaete Conference. Sydney: Linnean Society of New South Wales Press. P.181-196.

Hove H.A., ten, Kupriyanova E.K. 2009. Taxonomy of Serpulidae (Annelida, Polychaeta): The state of affairs // Zootaxa. Vol.2036. P.1-126.

Hove H.A., ten, Zibrowius H. 1986. Laminatubus alvini gen. et sp. n. and Protis hydrothermica sp. n. (Polychaeta, Serpulidae) from the bathyal hydrothermal vent communities in the eastern Pacific // Zoologica Scripta. Vol.15. No.1. P.21-31.

Howell B.F. 1962. Worms // Moore R.C., Teichert C. (eds.). Treatise on invertebrate paleontology. Pt.W. Miscellanea, Conodonts, conoidal shells of uncertain affinities, worms, trace fossils and problematica. Lawrence: Geol. Soc. Amer.; Univ. Kansas Press. P.W144-W177.
Ippolitov A.P., Rzhavsky A.V. 2008. On the tube microstructure of recent spirorbids (Annelida, Polychaeta) // Doklady Biological Sciences. Vol.418. P.20-22.

Jäger M. 1983. Serpulidae (Polychaeta Sedentaria) aus dem norddeutchen höheren Oberkreide - Systematik, Stratigraphie, Ökologie // Geologische Jahrbuch. Reihe A. Bd.68. S.1-219.

Jäger M. 1993. Danian Serpulidae and Spirorbidae from NE Belgium and EE Neitherlands: K $\backslash T$ Boundary extinction, Survivial and Origination Patterns // Contributions in Tertiary and Quaternary Geology. Vol.29. No.3-4. P.73-137.

Jäger M. 2005. Serpulidae und Spirorbidae (Polychaeta sedentaria) aus Campan und Maastricht von Norddeutschland, den Niederlanden, Belgien und angrenzenden Gebieten // Geologische Jahrbuch. Reihe A. Bd. 157 (für 2004). S.121-249.

Jäger M. 2011. Sabellidae, Serpulidae and Spirorbinae (Polychaeta sedentaria) from the Barremian (Lower Cretaceous) of the Serre de Bleyton (Drôme, SE France) // Annalen des Naturhistorischen Museums in Wien. Serie A. Bd.113. P.675-733.

Knight-Jones P. 1973. Spirorbinae (Serpulidae: Polychaeta) from south-eastern Australia. A new genus, four new subgenera and seven new species // Bulletin of the British Museum (Natural History). Vol. 24. No.4. P.231-259.

Knight-Jones P. 1978. New Spirorbidae (Polychaeta: Sedentaria) from the East Pacific, Atlantic, Indian and Southern Oceans // Zoological Journal of the Linnean Society, London. Vol.64. No.3. P.201-240.

Knight-Jones P. 1984. A new species of Protoleodora (Spirorbidae: Polychaeta) from eastern U.S.S.R., with a brief revision of related genera // Zoological Journal of the Linnean Society, London. Vol.64. No.2-3. P.109-120.

Knight-Jones P., Fordy M. 1979. Setal structure, functions and interrelationships in Spirorbidae (Polychaeta: Sedentaria) // Zoologica Scripta. Vol.8. No.2. P.119138.

Knight-Jones P., Knight-Jones E.W. 1977. Taxonomy and ecology of British Spirorbidae (Polychaeta) // Journal of the Marine Biological Association of the United Kingdom. Vol.57. No.2. P.453-499.

Knight-Jones P., Knight-Jones E.W. 1984. Systematics, ecology and distribution of southern hemisphere spirorbids (Polychaeta: Spirorbidae) // Hutchings P.A. (ed.). Proceedings of the First International Polychaete Conference. Sydney: Linnean Society of N.S.W Press. P.197-210.

Knight-Jones P., Knight-Jones E.W. 1991. Ecology and distribution of Serpuloidea (Polychaeta) round South America // Ophelia. Suppl. 5. P.579-586.

Knight-Jones P., Knight-Jones EW. 1994. Spirorbidae (Polychaeta) from Signy Island, South Orkneys, including three new species // Ophelia. Vol.40. No.2. P.75-94.

Knight-Jones P., Walker A.J.M. 1972. Spirorbinae (Serpulidae, Polychaeta) on limpets from the South Orkney Islands // British Antarctic Survey Bulletin. Vol.31. P.33-40. 
Knight-Jones P., Knight-Jones E.W., Buzhinskaja G.N. 1991. Distribution and interrelationships of Northern spirorbid genera// Bulletin of Marine Science. Vol.48. No.2. P.189-197.

Knight-Jones P., Knight-Jones E.W., Dales R.P.1979. Spirorbidae (Polychaeta: Sedentaria) from Alaska to Panama // Journal of Zoology. Vol. 189. No.4. P.419458.

Kupriyanova E.K. 2003. Life history evolution in Serpulimorph polychaetes: a phylogenetic analysis // Hydrobiologia. Vol.496. P.105-114.

Kupriyanova E.K., Macdonald T.A., Rouse G.W. 2006. Phylogenetic relationships within Serpulidae (Sabellida, Annelida) inferred from molecular and morphological data // Zoologica Scripta. Vol.35. P.421-439.

Kupriyanova E.K., Hove H.A., ten, Sket B., Zakšek V., Trontelj P., Rouse G.W. 2009. Evolution of the unique freshwater cave-dwelling tube worm Marifugia $\mathrm{ca}$ vatica (Annelida: Serpulidae)//Systematics and Biodiversity. Vol.7. No.4. P.389-401.

Lehrke J., Hove H.A., ten, Macdonald T.A., Bartolomaeus T., Bleidorn C. 2007. Phylogenetic relationships of Serpulidae (Annelida: Polychaeta) based on 18S rDNA sequence data, and implications for opercular evolution // Organisms Diversity and Evolution. Vol.7. P.195-206.

Linnaeus C. [as Linné C.] 1758. Systema Naturae per regna tria naturae, secundum classes, ordines, genera, species, cum characteribus, differentiis, synonymis, locis. Holmiae: Laurentius Salvius. $10^{\text {th }}$ ed. 824 p.

Lommerzheim A. 1979. Monographische Bearbeitung der Serpulidae (Polychaeta sedentaria) aus dem Cenoman (Oberkreide) am Südwestrand des Münsterlander Beckens // Decheniana. Bd.132. S.110-195.

Lommerzheim A. 1981. Paläozäne Serpulidae und Spirorbidae (Polychaeta) von der Emperor Seamounts, NWPazifik // Zitteliana. Bd.7. S.31-54.

Lowenstam H.A. 1954. Environmental relations of modification compositions of certain carbonate secreting marine invertebrates // Proceedings of the National Academy of Sciences of the USA. Vol.40. No.1. P.39-48.

Moore J.P., Bush K.J. 1904. Sabellidae and Serpulidae from Japan, with descriptions of new species of Spirorbis // Proceedings of the Academy of Natural Sciences, Philadelphia. Vol.56. No.1. P.157-179.

Nishi E. 1993. On the internal structure of calcified tube walls in Serpulidae and Spirorbidae (Annelida, Polychaeta) // Marine Fouling. Vol.10. No.1. P.17-20.

Pillai T.G. 1970. Studies on a collection of spirorbis from Ceylon together with a critical review and revision of spirorbid systematics, and an account of their phylogeny and zoogeography // Ceylon Journal of Science. Vol.8. No.1-2. P.100-172.

Pillai T.G. 2009. Knightjonesia, a new genus (Polychaeta: Spirorbidae) with a winged opercular peduncle, and its taxonomy // Zootaxa. Vol.2059. P.46-50.

Pixell H.L.M. 1912. Polychaeta from the Pacific coast of North America. Part I. Serpulidae, with a revised table of classification of the genus Spirorbis. // Proceedings of the Zoological Society of London. P.784-805.
Radwańska U. 1994. Tube-dwelling polychaetes from the Korytnica Basin (Middle Miocene; Holy Cross Mountains, Central Poland) // Acta Geologica Polonica. Vol.44. No.1-2. P.35-83.

Rafinesque S.C. 1815. L'analyse de la nature. Palermo. $224 \mathrm{p}$.

Rioja E. 1923. Estudio sistemático de las especies Ibéricas del suborden Sabelliformia // Trabajos del Museo Nacional de Ciencias Naturales. Serie Zoológica. Vol.48. P.5-144.

Rovereto G. 1903. Anellidi del Terziario // Rivista Italiana di Paleontologia. An.9. Fasc.4. P.103-104.

Rzhavsky A.V. 1994. On the morphoecology of spirorbid tubes (Polychaeta: Spirorbidae) // Ophelia. Vol.39. No.3. P.177-182.

Rzhavsky A.V. 1988. [Jugaria kofiadii sp. n. (Polychaeta, Spirorbidae) from the Arctic Basin] // Zoologicheskij Zhurnal. Vol.67. No.3. P. 933-935 [in Russian].

Rzhavsky A.V. 1997. Three new species and new genus of Spirorbidae (Polychaeta) from the Southern Indian Ocean, with a brief description of two species Incerta sedis from the southern hemisphere // Ophelia. Vol.46. No.3. P.233-245.

Rzhavsky A.V. 1998. Spirorbidae (Polychaeta) from the Adelie Land and Islands of Southern Indian Ocean // Abstracts of the Sixth International Polychaete Conference, Curitiba, Brazil 2-7 August 1998. P.124.

Rzhavsky A.V., Kupriyanova E.K., Sikorski A.V. 2013. Two new species of serpulid polychaetes from the Barents Sea // Fauna Norvegica. Vol.32. P.27-38.

Saint-Joseph M., de. 1894. Les annelides polychetes des cotes de Dinard // Annales des sciences naturelles. Vol.17. No.1. P.1-395.

Sanfilippo R. 1998a. Spirorbid Polychaetes as boreal guests in the Mediterranean Pleistocene // Rivista Italiana di Paleontologia e Stratigrafia. Vol.104. No.2. P.279-286.

Sanfilippo R. 1998b. Tube morphology and structure of the bathyal Maditerranean serpulid Hyalopomatus variorugosus Ben-Eliahu et Fiege, 1996 (Annelida, Polychaeta)// Rivista Italiana di Paleontologia e Stratigrafia Vol.104. No.1. P.131-138.

Sanfilippo R. 2001. Bathyvermilia islandica (Polychaeta, Serpulidae): a new deep-water species from south of Iceland // Sarsia. Vol.86. P.177-182.

Sanfilippo R. 2003. Climatic response in the genus Placostegus Philippi, 1844 from Plio-Pleistocene to Recent Mediterranean, with description of a new species (Polychaeta, Serpulidae) // Bolletino della Società Paleontologica Italiana. Vol.42. No.1-2. P.141-148.

Smith R.S. 1991. Relationships within the order Sabellida (Polychaeta) // Petersen M.E., Kirkegaard J.B. (eds.). Ophelia. Suppl.5. P.249-260.

Smith A.M., Riedi M.A., Winter D.J. 2013.Temperate reefs in a changing ocean: skeletal carbonate mineralogy of serpulids // Marine Biology. Vol.160. No.9. P.2281-2294.

Sterzinger I. 1909. Einige neue Spirorbis-Arten aus Suez // Sitzungsberichte der Kaiserliche Akademie der Wissenschaften, Wien, Mathematisch-Naturwissenschaftliche Klass. Bd.118. S. 1441-1459. 
Tanur A.E., Gunari N., Sullan R.M.A., Kavanagh C.J., Walker G.C. 2009. Insights into the composition, morphology, and formation of the calcareous shell of the serpulid Hydroides dianthus // Journal of Structural Biology. Vol.169. P.145-160.

Taylor P.D., Vinn O. 2006. Convergent morphology in small spiral worm tubes ('Spirorbis') and its palaeoenvironmental implications // Journal of the Geological Society (London). Vol.163. P.225-228.

Vine P.J. 1972. Spirorbinae (Polychaeta: Serpulidae) from the Red Sea, including description of a new species // Zoological Journal of the Linnean Society, London. Vol.51. No.2. P.177-201.

Vine P.J. 1977. The marine fauna of New Zealand: Spirorbinae (Polychaeta: Serpulidae) // New Zealand Oceanographic Institute Memoir. Vol.68. P.1-66.

Vinn O. 2005. The tube ultrastructure of serpulids (Annelida, Polychaeta) Pentaditrupa subtorquata, Cretaceous, and Nogrobs cf. vertebralis, Jurassic, from Germany // Proceedings of the Estonian Academy of Sciences, Geology. Vol.54. No.4. P.260-265.

Vinn O. 2007. Taxonomic implications and fossilization of tube ultrastructure of some Cenozoic serpulids (Annelida, Polychaeta) from Europe // Neues Jahrbuch für Geologie und Palaontologie, Abhandlungen. Vol.244. No.1. P.115-128.

Vinn O. 2008. Tube ultrastructure of the fossil genus Rotularia Defrance, 1827 (Polychaeta, Serpulidae) // Journal of Paleontology. Vol.82. No.1. P.206-212.

Vinn O. 2013. SEM study of semi-oriented tube microstructures of Serpulidae (Polychaeta, Annelida): implications for the evolution of complex oriented microstructures // Microscopy Research and Technique. Vol.76. P.453-456.

Vinn O., Kupriyanova E.K. 2011. Evolution of a dense outer protective tube layer in serpulids (Polychaeta, Annelida) // Carnets de Géologie [Notebooks on Geology]. Letter CG2011/05 (CG2011_L05).

Vinn O., Mutvei H. 2009. Calcareous tube-worms of the Phanerozoic // Estonian Journal of Earth Sciences. Vol.58. P.286-296.
Vinn O., Taylor P.D. 2007. Microconchid tubeworms from the Jurassic of England and France. // Acta Palaeontologica Polonica. Vol.52. No.2. P.391-399.

Vinn O., Hove H.A., ten, Mutvei H., Kirsmae K. 2008a. Ultrastructure and mineral composition of serpulid tubes (Polychaeta, Annelida) // Zoological Journal of the Linnean Society. Vol.154. P.633-650.

Vinn O., Mutvei H., Hove H.A., ten, Kirsimäe K. 2008b. Unique Mg-calcite skeletal ultrastructure in the tube of the serpulid polychaete Ditrupa // Neues Jahrbuch für Geologie und Paläontologie, Abhandlungen. Vol.248. No.1. P.79-89.

Weedon M.J. 1990. Shell structure and affinity of vermiform "gastropods" // Lethaia. Vol.23. P.297-309.

Weedon M.J. 1991. Microstructure and affinity of the enigmatic Devonian tubular fossil Trypanopora // Lethaia. Vol.24. P.227-234.

Weedon M.J. 1994. Tube microstructure of recent and Jurassic serpulid polychaetes and the question of the paleozoic spirorbids // Acta Palaeontologica Polonica. Vol.39. No.1. P.1-15.

Zachs I.G. 1933. [On the annelid fauna of the Northern Sea of Japan] // Issledovanija Morej SSSR. Vol.19. P.125137 [in Russian].

Zibrowius H. 1972. Un espèce actuelle du genre Neomicrorbis Roverto (Polychaeta Serpulidae) découverte dans l'étage bathyal aux Açores // Bulletin du Muséum d'Histoire Naturelle, Paris. Ser. Zool. T.33. No.3. P.423-430.

Zibrowius H., Hove H.A., ten. 1987. Neovermilia falcigera (Roule, 1898) a deep- and cold-water serpulid polychaete common in the Mediterranean Plio-Pleistocene // Bulletin of Biological Society of Washington. Vol.7. P.259-271.

Zittel K.A., von. 1880. Handbuch der Palaeontologie. Abt.I. Bd.II. Protozoa, Coelenterata, Echinodermata und Molluscoidea. München, Leipzig: R. Oldenbourg. viii+ $765 \mathrm{~S}$.

Responsible editors K.G. Mikhailov, E.N. Temereva 